Volume 13

\title{
Book Review: Forced Confrontation: The Politics of Dead Bodies in Germany at the End of World War II
}

Christiane K. Alsop

Van Loan School at Endicott College

Follow this and additional works at: https://digitalcommons.usf.edu/gsp

\section{Recommended Citation}

Alsop, Christiane K. (2019) "Book Review: Forced Confrontation: The Politics of Dead Bodies in Germany at the End of World War II," Genocide Studies and Prevention: An International Journal: Vol. 13: Iss. 1:

191-194.

DOI:

https://doi.org/10.5038/1911-9933.13.1.1648

Available at: https://digitalcommons.usf.edu/gsp/vol13/iss1/17

This Book Review is brought to you for free and open access by the Open Access Journals at Digital Commons @ University of South Florida. It has been accepted for inclusion in Genocide Studies and Prevention: An International Journal by an authorized editor of Digital Commons @ University of South Florida. For more information, please contact digitalcommons@usf.edu. 


\title{
Book Review: Forced Confrontation: The Politics of Dead Bodies in Germany at the End of World War II
}

\author{
Christiane K. Alsop \\ Van Loan School at Endicott College \\ Beverly, Massachusetts, USA
}

Forced Confrontation: The Politics of Dead Bodies in Germany at the End of World War II Christopher Mauriello

Lanham, Lexington Books, 2017

211 Pages; Price: $\$ 96.63$

Reviewed by Christiane K. Alsop

Van Loan School at Endicott College

This book is the stuff of nightmares: Nazi concentration camp victims on their death march in the last days of World War II, beaten, tortured, mutilated, shot, then hastily hidden along the roads of Bavarian towns or tossed into mass graves in surrounding forests and fields. The closer the enemy armies came, the more brutally SS officers and camp guards attacked their charges, hitting them with rifle butts, kicking them with their leather boots, smashing them with their spades, and shooting them once, twice, or many times. If the German townspeople witnessed these atrocities, they did not admit to it. Instead they claimed they had never been Nazis, had never even known any, had been victims themselves-refusing responsibility for the atrocities discovered in and around their towns.

For a second-generation German like me, this brings up painful personal questions. I look at my pencil marks on the pages of this book, testimony to my struggles to stay focused. I turn the page. My eyes fixate on one of the many photographs reproduced in this historical study. It shows women in the midst of a dense forest carrying an open casket on two wooden bars. Sunlight falls on the face of the woman on the left, exposing the pain she feels at the weight of her burden, a victim of Nazi terror. The woman on the right, however, un-illuminated by beams of sunlight, has a rigid expression. The number 57 has been engraved on the front of the casket. It is open. I can see a hat but no face, an elbow sticking out on the left side of the coffin. Are the legs crossed? The boots visible at the end of the coffin hint as much - the left is on the right side and vice versa - or perhaps something worse.

For the author of this historical study, Christopher Mauriello, a professor of history and the director of the Center for Holocaust and Genocide Studies at Salem State University in Massachusetts, these nightmare scenarios are personal too. His father was part of the advancing U.S. army, yet his letters home to his family "reflected no hostility towards the German civilians $[\ldots]$, no accusations of collective guilt for Nazi crimes."

What to make, then, of the fact that the American troops did carry out this punishment of forced confrontation against the local people: forcing them to dig up and reinter the bodies buried along the roads and in mass graves around little towns in the hills and mountains of Eastern Bavaria close to the border to Czechoslovakia?

These troops had been trained to expect heavy combat. Yet when they occupied the region, they encountered no overt resistance, only a passive, compliant population. April rains had turned the grounds into mud, exposing dead bodies along the roads and in mass graves in the surrounding fields and forests. The smell of decay hung in the air. The troops realized with horror that just before they had been approaching, atrocities had been committed everywhere, while they "were powerless to stop it." ${ }^{2}$ And no sooner had the Americans arrived than the SS murderers had shed their uniforms to hide their identities, while local politicians hastily destroyed evidence of the towns peoples' complicity with the Nazi regime. Who was to blame? Without waiting for

\footnotetext{
${ }^{1}$ Christopher Mauriello, Forced Confrontation: The Politics of Dead Bodies in Germany at the End of World War II (Lanham: Lexington Books, 2017), viii.

${ }^{2}$ Ibid., 183
} 
criminal investigations, court hearings or decisions from politicians, the U.S. officers and soldiers became judges, juries and executioners assigning collective guilt and handing down sentences of forced confrontation. They could do so because in the midst of the confusion of fighting a war and administering an occupation, American field commanders and the military government had been given extraordinary autonomy to act. Although these confrontations varied slightly at the four different sites on which the author focuses his investigation, all of them had these elements:

- ordering German townspeople to dig out the corpses along the roads or in mass graves;

- building individual coffins for the victims;

- forced spectatorship of lines of open caskets or open graves; forced processions of coffins through town;

- burials in town cemeteries or in town centers organized and attended by the American Forces, American clergy, local clergy and survivors of the death marches.

Funerals for the victims became the occasions for insisting on collective guilt. In one town, Ludwigslust in Mecklenburg, an American chaplain put it this way:

Though you claim no knowledge of these acts you are still individually and collectively responsible for these atrocities, for they were committed by a government elected to office by yourself in 1933 and continued in office by your indifference to organized brutality. ${ }^{3}$

Mauriello relies on primary and secondary sources from official civilian and military archival materials in the United States and Germany, on his own and other scholars' oral histories, on documents from private collections, on photographs, on published and unpublished accounts, and on newspaper clippings, as well as materials from reputable websites. The author weaves together these manifold details using Clifford Geertz' thick description, a methodology, in which scientific observations of human behavior get embedded in the context in which they take place considering the subjective explanations and the meaning-making by those involved. The study is based on two theoretical frameworks: Victor Turner's concept of liminality refers to fluid, ambiguous situations that are experienced as profoundly disorienting and threatening to the point that they can almost dissolve identity, but also as impetuses for those affected to change their outlooks and behavior; Katharine Verdery studied the politics of dead bodies in postwar Europe. Further elaborations on the author's understanding und use of this methodology and the concept of liminality would have been helpful.

In six chapters this book describes the American military's reactions to the discovery of the dead bodies and scattered mass graves in the Bavarian towns of Nordhausen, Schwarzenfeld, and Neunburg vorm Wald, as well as to those of the victims at the Wöbbelin concentration camp near the town of Ludwigslust, some 300 miles north in Mecklenburg. While the killings at concentration camps had taken place in a fixed location, those that took place during the death marches resulted in scattered, non-linear zones of death. The author's descriptions embed each forced confrontation and assignment of collective guilt in the context of its physical site, the social conditions, the local politics and the characters emerging as agents of the situation. The chaos, violence and tragedies seemed to increase with each newly discovered site. Death marches had intersected and thousands of starving, beaten, and exhausted death-march prisoners had joined thousands of other displaced persons ahead of the approaching U.S. armored and infantry divisions. ${ }^{4}$ Every new event drew more and more arriving war correspondents, signal corps photographers and film crews. As occurred in other post-war reckoning scenarios, ${ }^{5}$ here too the community's women became the

\footnotetext{
${ }^{3}$ Ibid., 182.

${ }^{4}$ Ibid., 88.

${ }^{5}$ Keith Lowe describes the public shaming, extraordinary violence, torture, and in some cases murder, men in various European countries inflicted on those women who had had sexual relationships with a German occupier in his chapter "Revenge on Women and Children" within Savage Continent: Europe in the Aftermath of World War II 1943-1950 (New York: St. Martin's Press, 2012).
} 
objects of scorn. They were made to carry the open caskets through the town under the eyes of former victims of various national, ethnic, religious, and political background. As Mauriello puts it: "The gendered ideal of women as maternal receptacles for reproduction of new life was inverted through the perverse ideology of Nazism into a new representation of woman as culpable carriers of death." 6

With each site, the assigned collective guilt expanded in scope to "all Germans in a vast murderous conspiracy that included the use of forced labor for the benefit of Germans and Germany." 7 In Nammering, where the sheer number of dead bodies made for the largest forced confrontation by the American military, the troops tried to use forced confrontation to educate hundreds or even thousands of German civilians at the point of a gun. They compelled German children, women and the elderly, as representatives of the perpetrators, to read their sign: "Here lies [sic] 800 murdered bodies killed by the Nazis of Namering [sic], Germany in April 1945." them walk barefoot past partially covered dead bodies, some bloated from decomposition, faces, legs and feet exposed. The residents had to heave the dead bodies into the caskets with bare handsthe use of gloves was explicitly forbidden-and carry them on oxen transports over potholed dirt roads. ${ }^{9}$ During the postwar years that followed, Jewish committees and other victim groups, as well as local and national politicians in the newly established Federal Republic of Germany, initiated the reburials of victims at various sites, while emerging postwar narratives changed the understanding, use, abuse, and rejection of the concept of collective guilt.

The violent events this book describes, and the complexity of the forces at play tend at times to overwhelm the narrative. The point of view changes frequently, while different sources develop their own plotlines. ${ }^{10}$ While the account derives much of its power and conviction from its painstaking attention to detail, that same detail sometimes threatens to overwhelm the larger picture, defeating the purpose of thick description. Mauriello's central point seems to be that the policy of forced confrontation was the spontaneous, on-the-ground response of American military commanders to the liminal situation they found themselves and their troops in at the discovery of the atrocities that had taken place. The policy was not ordered by the president or by any other governmental institutions or military headquarters. Mauriello's research succeeds in capturing the U.S. soldiers' urgent need to process and make meaning of atrocities of unknown scale and proportion. In the presence of both living and dead victims, and in the absence of identifiable perpetrators, these soldiers attributed responsibility to all those who did nothing to prevent the crimes. Their attempt at meaning making led them to assign the binary order of fighting for the good (the U.S. military forces) versus condemning evil (all Germans); and to try to reverse the dehumanization caused by the Nazi terror by re-individualizing the victims. In the hope of re-establishing the American values of democracy and freedom they decided to punish and re-educate the German townspeople by staging forced confrontation and assigning guilt. ${ }^{11}$

However, because the American forces were unable to ascertain individual levels of engagement in the Nazi terror regime, their efforts also had the effect of dehumanizing the Germans by assigning collective guilt to everyone. Their forced confrontations must have created an experience of liminality in the German townspeople just as the American troops experienced in discovering the atrocities. But unfortunately, the author's attempts at capturing the reactions of German civilians fall short of his ambitions. German civilian responses are only hinted at and sparsely

\footnotetext{
${ }^{6}$ Mauriello, Confrontation, 103.

${ }^{7}$ Ibid., 110.

${ }^{8}$ At the time the sign was composed Americans weren't yet aware that the dead bodies they had discovered were victims from Buchenwald, nor did they know the specifics of the killings in Nammering. They conceived of the atrocities as local expressions of Nazi fanaticism (Ibid., 130).

${ }^{9}$ As in the other cases of forced confrontation, the victims were given Christian, mostly Catholic burials. In later years local Jewish Communities initiated re-burials along Jewish rituals.

${ }^{10}$ The subchapter "Burying the Nazi Past: Schwarzenfeld on the Eve of Liberation" within Chapter 3 or the subchapter "Postwar Forced Confrontations and the Ghosts of Neunburg Vorm Wald" within Chapter 6 shall serve as examples in Mauriello, Confrontation.

${ }^{11}$ Ibid., 182.
} 
documented. In part, Mauriello says, this imbalance is due to a lack of sources and "to the futility and basic unfairness of asking any surviving witnesses to relate their feelings or thoughts from over seventy-five years ago when most were still children." ${ }^{12}$ Yet the reader is left to wonder: don't thick description and historiography always have to take the partiality and the special circumstances of oral history and witness accounts into consideration? Christopher Mauriello himself expertly documents the value of such oral history when documenting the reactions of military forces to their discoveries. And even though Mauriello did not include the German townspeoples' reactions, he could have considered other major and successful efforts among historians and other social scientists to capture Germans' experiences and interpretations of the war and the Holocaust. ${ }^{13}$

On a national level, the reactions to collective guilt are no less complex. While, as Mauriello states, Germans resisted the attribution of collective guilt, he does not acknowledge their sense of general responsibility, even though to a degree it is evident in some of his own sources, and has been extensively documented in the discussions and publications of postwar German intellectuals like Karl Jaspers and Hannah Arendt. ${ }^{14}$ This German sense of guilt explains, at least in part, why for decades the social, emotional and physical consequences of the Allied air raids and the displacement of millions of Europeans were buried in the German collective consciousness. ${ }^{15}$ And while initiatives such as the "Stolpersteine" - small bronze stumble-stones stamped with the names of victims embedded in the sidewalks outside their former residences-individualize victims of Nazi terror who were abducted to concentration camps and other sites of mass murder, nevertheless, when a photo exhibition in the 1990s documented the genocidal atrocities committed by ordinary German Wehrmacht soldiers, ${ }^{16}$ the myth of the SS as the major agent of evil was still so prevalent that the exhibition ignited vehement protest and renewed denial in segments of the German population. Mauriello concludes that the politics of dead bodies may have been local in the last months of the war but became national and global in the postwar years. Yet his account of these developments becomes murky at times, overgeneralizing and leaving out the efforts of other key players of the postwar era like the British, French, and Soviet occupying forces.

This historical study expertly captures a phenomenon of significant importance to all genocide researchers: the struggles of those who discover genocidal atrocities and are left (in the absence of more formal systems of justice) to attribute guilt and to exact retribution. In this case, the spontaneously emerging policy of forced confrontation demonstrated the American troops' efforts at making meaning by re-establishing a sense of individuality for the Holocaust victims while, in the absence of identifiable perpetrators, assigning collective guilt. Mauriello's book suggests the value of such efforts while bearing witness to their complex results.

\footnotetext{
${ }^{12}$ Ibid., 186.

${ }^{13}$ Although not originating in the towns the author investigates, the memoirs of the U.S. intelligence officer, psychologist and historian, Saul K. Padover provides vivid descriptions of German civilians' responses to the war and the atrocities: Experiment in Germany: The Story of an American Intelligence Officer (New York: Duell, Sloan \& Pearce, 1946). As for a contemporary account, see Nicholas Stargardt's The German War. A Nation Under Arms, 1939-1945 (New York: Basic Books, 2015).

${ }^{14}$ Giles MacDonogh, After the Reich: The Brutal History of Allied Occupation (New York: Basic Books, 2009), $340,341$.

${ }^{15}$ The writer W.G. Sebald elaborates on the motives and the consequences of the Allied bombings in his book On the Natural History of Destruction (New York: The Modern Library, 2004); the historian Keith Lowe describes the chaos caused by the millions on the move at the end of World War II and the postwar years in his book Savage Continent: Europe in the Aftermath of World War II 1943-1950 (New York: St. Martin's Press, 2012).

${ }^{16}$ Hamburger Institut für Sozialforschung (Hg.), Vernichtungskrieg. Verbrechen der Wehrmacht 1941 bis 1944. Ausstellungskatalog (Hamburg: Hamburger Edition, 1996).
} 